\title{
The impact of big-5 model leadership traits on team entrepreneurship: An empirical study of small businesses in the UAE
}

\author{
Adnan Jawabri ${ }^{a^{*}}$
}

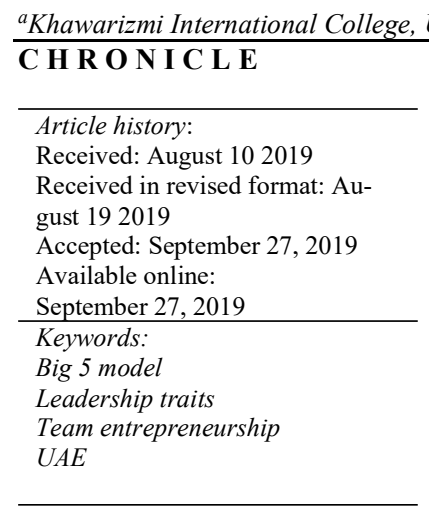

\begin{abstract}
A B S T R A C T
Entrepreneurs who are operating small businesses focus on faster growth of their firms through greater wealth creation. This wealth creation process requires skill and investment in terms of time and capital. However, the success or failure of entrepreneurial teams depends on personality differences among the entrepreneurs. In this context, the present study explores the impact of the Big 5 model traits on the team entrepreneurship and the performance of the ventures among the small businesses in the UAE. Further, the study encapsulates how these personality traits can help in solving business problems and achieving long term success for the business. In this regard, the researcher conducted a survey on 49 employees working in 5 entrepreneurial businesses in UAE. The findings of the study highlighted that sub-factors of big five leadership traits broad-minded, gregarious, assertive, responsible, anxious and emotionally depressed, significantly impact the team entrepreneurship of small businesses in the UAE, aiding in increased customer base, venture skills, stock values, and innovating of new products.
\end{abstract}

\section{Introduction}

The present decade is witnessing a rapid increase in innovation of products and services. This increase can be attributed to the growing competition in the market which has encouraged entrepreneurs to develop new business models with specific focus on innovation (Narea, 2016). These business models serve multiple purposes, such as creation of competitive advantage, and satisfying the customer needs. The quest for innovation assists business to function through complex segments that can in turn generate success for the organization. This task is difficult for an individual entrepreneur with limited skills, ideas and proficiency (Maxwell, 2013; Skripak, 2016). It is in this context that entrepreneurial teams play an important role. They ensure better success for an organization as they create a single platform through which individual entrepreneurs possessing different set of skills and expertise can come together to share their ideas, resources and competencies (Yan, 2018). The entrepreneurs involved in teamwork possess the traits of assertiveness, critical thinking and creativity. This team can develop broad vision for their organization which can drive the energy and talent of the team players in the right direction, and carry the openmindedness needed to achieve success. The team players continuously work for new innovations that can derive the growth of the business beyond their expectations (Schilirò, 2015). Another critical element that plays a key role in determining entrepreneurial success is personality traits of the leader/ entrepreneur. Research has consistently linked the two elements, with different researchers examining how specific personality traits play a role in business performance (Kumaran et al., 2017; Narea, 2016; Singh, 1997; Yan, 2010). In this context, the concept of Big Five personality traits proposed by Goldberg (1981, 1990) has represented a promising foundation in research related to entrepreneurship. This paper will delve into the phenomenon of team entrepreneurship, connecting the big 5 traits of each entrepreneur in a team to entrepreneurial success.

\footnotetext{
* Corresponding author.

E-mail address: Adnan.Tahir@Khawarizmi.com (A. Jawabri) 
United Arab Emirates has emerged as one of the fastest growing business markets in the Arabian Gulf region. The economy is experiencing a diversified and innovative growth in the business markets among all the Arab nations (Schilirò, 2015). This innovation is attributed to the rise in the number of small scale enterprises that are making significant contribution to the innovation domain (George, 2018; Hamdan, 2019). The growth among the small-scale enterprises has generated vast scale growth opportunities for the young population. With the rise in the number of entrepreneurship teams, UAE has emerged as one of the countries which has developed a positive attitude towards innovation. Most of these start-ups are focusing on developing new and unique goods and services for its customers. Apart from this, the public sector in UAE is also witnessing a rise and has crowded out the entrepreneurship which was earlier thrived only by the private sector (Kuckertz \& Berger, 2017). In order to build a skilled and experienced workforce, the government of UAE has also taken up initiatives for providing training and education to the young population, whereas the private sector has taken up measures for human capital development. This process includes developing the skill set of their existing workers who can adapt to the changing economy (Khan et al., 2014).

The main aim of this study is to explore the impact of Big-5 personality traits of leaders on team entrepreneurship among small businesses in the UAE.

\section{Literature Review}

\subsection{Meaning of team entrepreneurship and how it is different from individual entrepreneurship}

Entrepreneurship is the multidimensional concept that involves discovery, evaluation and exploitation of new opportunities. This process includes a high degree of supervision to manage the risks and uncertainties associated to its outcomes. The individual entrepreneurs who are committed towards the organization goals can act as a strong leader (Darnihamedani, 2016). However, the success of the organization depends on set of personal, social, political and cultural factors. In addition to this, it depends on knowledge, skills, technology and investment undertaken by the entrepreneurs. Further, the present era of high intensity of competition requires new innovation and ideas for business development. None of these things can be managed by an individual entrepreneur and hence has developed the need of team entrepreneurship (Yan, 2018). In addition to this, the team players act as a source of support for each other through better decision making. Effective decision-making process attributes to the fact that decision-making process among the teams involves series of debates and discussions. These discussions assist the team players in examining the pros and cons of each decision. Thus, each decision is taken after deep investigation and evaluation that generates effectiveness in the decision making process (Antoncic et al., 2018). The decision-making process among the team players requires evaluation of information, unstructured events and uncertain opportunities. However, one of the likely outcomes in the market is the absence of information which puts the business into risk (Matriano \& Suguku, 2015). This is particularly correct for the small businesses or start-ups that undergo varied complexities and uncertainties that can generate problems for the smooth functioning of the business. This problem can be solved through team entrepreneurship that involves effective management and distribution of risk among the team members (Ugwoke et al., 2013).

\subsection{Big Five Personality Traits}

Though team entrepreneurship offers multiple benefits in comparison with the individual entrepreneurship, the success of the organization largely depends on the psychological behavior of the entrepreneurs. This psychological behavior defines the personality traits of the entrepreneurs. These personality traits are directly linked to the success or failure of the business. In this regard, the study of Antoncic et al. (2015) identified the 5 model approach to measure the impact of personality on entrepreneurial success. It is compelling and widely accepted approach to examine the personality traits of the entrepreneurs. The five personality traits include openness to experience, conscientiousness, extraversion, agreeableness and neuroticism (Antoncic et al., 2015; Murugesan \& Jayavelu, 2017). These five traits are not affected by any specific event and examine the reaction of entrepreneurs on different set of circumstances faced that any business. Apart from this, the five personality traits are defined by certain set of characteristics and their which are explained below:

\subsubsection{Openness to experience}

Openness of experience defines the mental and experiential life of the entrepreneur that comprise of broadness, deepness and complexities. The study of Kerr et al. (2018) highlighted that openness can drive the success even in complex job settings . It includes the ability to negotiate with the changing market conditions. In other words, it examines the entrepreneurs' ability to drive the business towards the success. In this regard, the study conducted by Wilfling and Silbereisen (2011) highlighted that entrepreneurs who are open to new experiences take better decisions in managing the business. In the same context, the study of Shane (2010) highlighted that openness to experience is characterized by the entrepreneurs ability to derive imaginative and creative solutions for the business problems. In addition to this, the entrepreneurs who are broad minded can develop effective environment for the team players which in turn helps them in taking better decisions.

\subsubsection{Conscientiousness}

Conscientiousness is defined as the task oriented or the goal-oriented behavior of the entrepreneurs. The study conducted by Antoncic et al. (2015) highlighted some of the traits which are attributed to this factor. These traits include thinking before acting, delaying gratification, planning, organizing and assigning the tasks. These attributes are directly linked to the job 
performance and hence play an important role in defining the success or failure of the organization. The study of Kerr et al. (2018) also linked conscientiousness to the level of task accomplishment. The study made a comparison in terms of conscientiousness among the managers and entrepreneurs. The study conducted by Farwizah et al. (2018) highlighted that conscientiousness is characterized by the extent of responsibility displayed by the entrepreneurs towards the organizational goals. In addition to this, it defines the entrepreneur's commitment to achieve high level of success. Entrepreneurs who are responsible and committed towards the organization goals can lead the organization in the right direction.

\subsubsection{Extraversion}

Extraversion is attributed to the entrepreneur's attitude or approach towards the social and material environment. This factor is related to characteristics like sociability, assertiveness and gregarious of the entrepreneurs. These characteristics define the enthusiastic or motivated behavior of the entrepreneurs. In this context, the study of Farwizah et al. (2018) highlighted the importance of extraversion among the entrepreneurs. The entrepreneurs are the head or the agents continuously involved in exchange of ideas and opinions with the investors, employees and the customers. To this, the study of Antoncic et al. (2015) stated that the entrepreneurs who are more assertive act as better leaders because they encourage their employees for equal participation in decision making. Moreover, gregarious and socially active attitude displayed by the entrepreneurs helps in strong team building and community involvement.

\subsubsection{Agreeableness}

Agreeableness is defined as the extent to coordination or cooperation that employees display towards the organization. In this context, the study of Antoncic et al. (2015) highlighted the importance of agreeableness in determining the relationship of the entrepreneurs with the employees and the customers. In addition to this, this factor also plays a vital role in framing interactions and negotiations with the stakeholders. Further, the study of Kerr et al. (2018) stated that agreeableness also helps the small businesses or start-ups to raise funds from the external financers which in turn determine the life span of the business.

\subsubsection{Neuroticism}

Neuroticism is the tendency of the entrepreneurs to display a psychology adjustment and the emotional stability. It renders to the anxiousness and negative emotions of the entrepreneurs. In this context, the study of (Kerr et al., 2018) highlighted that Neuroticism is concerned with the negative attitude of the entrepreneurs that indicates their weak psychological health. To this, the study of Farwizah et al. (2018) focused on the negative impact of neuroticism on the entrepreneurship teams. The study highlighted that higher degree of neuroticism generates lower outcome for the team work.

\subsection{Factors determining the success of team entrepreneurship}

The success of the entrepreneurial team depends on the proactive behavior and the locus of control displayed by the team players. Individual entrepreneurs often lack in terms of the ideas and gets trap in risky situations. The study of Zaccaro et al. (2001) stated that team entrepreneurship often develop creative solutions by exploring new fields for which the team players exert extra efforts. The proactive behavior displayed by the team players can generate new opportunities for the growth of the business. The assertive behavior among the team players gives them complete control over the business and derives the business towards the path of success. The business traits are formed by the combination of traits that can be described though qualities of creativity, imagination, philosophical, intellectual, and complex functioning (Markuerkiaga et al., 2014). The big five personality traits can help in solving the complex business problems that hinders the growth of start-ups and entrepreneurship teams operating small businesses. The creative aspect of openness encourages the entrepreneurs to do their business in their own ways. These entrepreneurs can build a strong network of relationship among the suppliers and customers in turn exerting the extraversion attribute which can make the entire team more social and forge the relationships for business survival.

\subsection{Impact of successful team entrepreneurship on business performance}

Entrepreneurial teams comprise of people with different specializations and therefore help in diverse decision-making. Diverse decision making plans help improve the satisfaction between different members of an entrepreneurial team and improves integration among the group members (Vyakarnam \& Handelberg, 2005). Increased integration indicates better communication between the team members that leads to development of innovative services and products. Innovative services and products help the new venture attract customers from all segments (Yoon, 2018). Increased customers mean the financial performance of the venture increases from the sales of the innovative services or product developed. However, entrepreneurial teams simply do not measure their growth on the increase of sales; it is also based on increasing the number of members or employees of the venture. This not only helps in improving the efficiency of the business operations but also helps the venture diversity in the amount of skill (Diakanastasi et al., 2018). Diversification allows the ventures to become competitive in the market and may also provide with competitive advantages over other organizations. An increased competition will let the entrepreneurial teams further improve on innovations (Vyakarnam \& Handelberg, 2005). In addition, the performance of the venture also measured on the basis of the satisfactions and customer relations. Customer relations and feedback allows the ventures to envisage on improving their operations and services. According to Kamm et al. (2018), the entrepreneurial teams are responsible for improving the stocks and shares of their ventures. Therefore, the entrepreneurial team has a positive impact on the business performance. 


\section{Empirical review}

In Table 1, the empirical review of the literatures that informs about the use of any of the Big 5 leadership factors as identified by Antoncic et al. (2015) has been presented. The analytical findings of all the empirical papers found significance of openness to experience, conscientiousness, extraversion, agreeableness and neuroticism towards to impact the team entrepreneurship amongst leaders.

Table 1

Empirical review

\begin{tabular}{|c|c|c|c|}
\hline Author & Aim & Success factors & Findings \\
\hline $\begin{array}{c}\text { (Hwee Nga \& } \\
\text { Shamuganathan, 2010) }\end{array}$ & $\begin{array}{l}\text { To find out whether all big five fac- } \\
\text { tors of personality will have positive } \\
\text { effect on the new ventures likelihood } \\
\text { of survival and its overall life span }\end{array}$ & None & $\begin{array}{l}\text { A negative relationship between the entrepre- } \\
\text { neur's openness and long term venture survival } \\
\text { was found. Extraversion, emotional stability, } \\
\text { agreeableness were not related to long term } \\
\text { venture survival. }\end{array}$ \\
\hline $\begin{array}{l}\text { (Diakanastasi et al., } \\
\text { 2018) }\end{array}$ & $\begin{array}{l}\text { The objective of the paper is to ex- } \\
\text { plore several factors that could influ- } \\
\text { ence the digital entrepreneurial team } \\
\text { dynamics and the affect the stability } \\
\text { or resolution of the team through the } \\
\text { different stages of the new venture } \\
\text { creation }\end{array}$ & $\begin{array}{l}\text { The number of participants, the } \\
\text { commitment to the team, how } \\
\text { well the roles of each other are } \\
\text { set and the existence of the cou- } \\
\text { ple }\end{array}$ & $\begin{array}{l}\text { These factors put the team under real pressure } \\
\text { and test there endurance and this would ulti- } \\
\text { mately affect the outcome of the new venture } \\
\text { performance. }\end{array}$ \\
\hline (Kamm et al., 2018) & $\begin{array}{l}\text { To explore the key entrepreneurial } \\
\text { characteristics of the top managers } \\
\text { and the impact of them on the firm } \\
\text { performance. }\end{array}$ & $\begin{array}{l}\text { High tolerance of risk, favor in- } \\
\text { novative activities, high degree } \\
\text { of proactiveness }\end{array}$ & $\begin{array}{l}\text { The paper also examined the influence of top } \\
\text { manager's prestige, structural and expert power } \\
\text { on the relationship between entrepreneurial ori- } \\
\text { entation and the firm performance. The results } \\
\text { showed that there is positive correlation be- } \\
\text { tween the two and points out that it is important } \\
\text { for determining efficacy. }\end{array}$ \\
\hline (Brandstätter, 2011) & $\begin{array}{l}\text { To find out whether the system of } \\
\text { big five personality traits make a dif- } \\
\text { ference when entrepreneurs are com- } \\
\text { pared with mangers }\end{array}$ & $\begin{array}{l}\text { Readiness for innovation, proac- } \\
\text { tive personality, generalized self- } \\
\text { efficacy, stress tolerance, need } \\
\text { for autonomy and the locus of } \\
\text { control }\end{array}$ & $\begin{array}{l}\text { These factors are relevant in predicting entre- } \\
\text { preneurial intention and entrepreneur's perfor- } \\
\text { mance. }\end{array}$ \\
\hline (Zhao \& Seibert, 2006) & $\begin{array}{l}\text { To examine the relationship between } \\
\text { personality and entrepreneurial sta- } \\
\text { tus }\end{array}$ & $\begin{array}{l}\text { Conscientiousness, openness to } \\
\text { experience }\end{array}$ & $\begin{array}{l}\text { The study showed the entrepreneurs scored } \\
\text { higher on conscientiousness and openness to } \\
\text { experience and lower on neuroticism and } \\
\text { agreeableness. No difference was found for ex- } \\
\text { traversion. Effect size for each personality di- } \\
\text { mension was small. }\end{array}$ \\
\hline
\end{tabular}

\section{Conceptual framework}

In order to address the aim of the study, a conceptual framework was formed whereby it was implicated that the Big-5 personality traits of leaders has a positive impact on the success of team entrepreneurship which indirectly impacts the performance of small businesses and ventures (See Fig. 1).

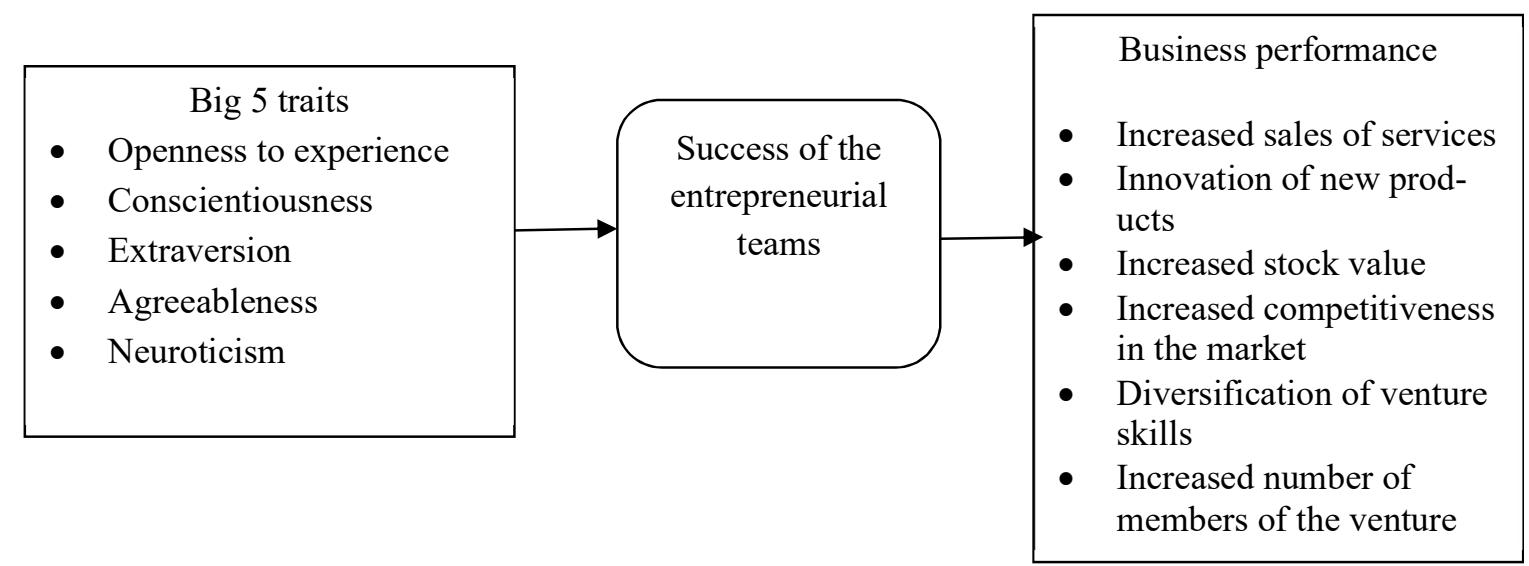

Fig. 1. The proposed study 


\section{Methodology}

The current study is based on an empirical quantitative research methodology that uses the exploratory research design to assess the impact of the big 5 leadership personality traits on team entrepreneurship amongst the small businesses of UAE. Since the study used a quantitative method, a deductive research approach was chosen to implicate if it comprises of leadership traits like openness to experience, conscientiousness, extraversion, agreeableness and neuroticism and their impact on team entrepreneurship. In order to conduct the research, 5 entrepreneurial businesses in UAE were approached with the scope and purpose of the study. The main aim of targeting the employees from small businesses with entrepreneurial teams was to assess which of the identified business performance measures were most significant for their organizations. Initially the employees were asked about the perceived personality characteristics of their entrepreneurial teams. The perspectives of the employees helped to assess the significance of these traits towards the success of the team and the organization. In addition, asking about the business performance characteristics, the study also helped to perceive the most significant performance values of the business ventures in UAE. On gathering the data from the employees about their personal details and their perspectives on personality traits and business performance, the data was run for statistical assessments on SPSS v23 software. Reliability of the study was conducted using Cronbach alpha test where the values for traits and business performance were very high at .982 and .968 respectively.

\section{Analysis}

\subsection{Descriptive analysis}

In this section, the description of the demographic and the general background of the respondents have been presented. The findings are presented in graphs and tabular form for cross tabulation part.

\subsubsection{Frequency distribution of demographic profile}

In Fig. 2, there is gender biasness amongst the respondents of the study. $61.2 \%$ of the respondents/employees were male whereas $38.8 \%$ were female.

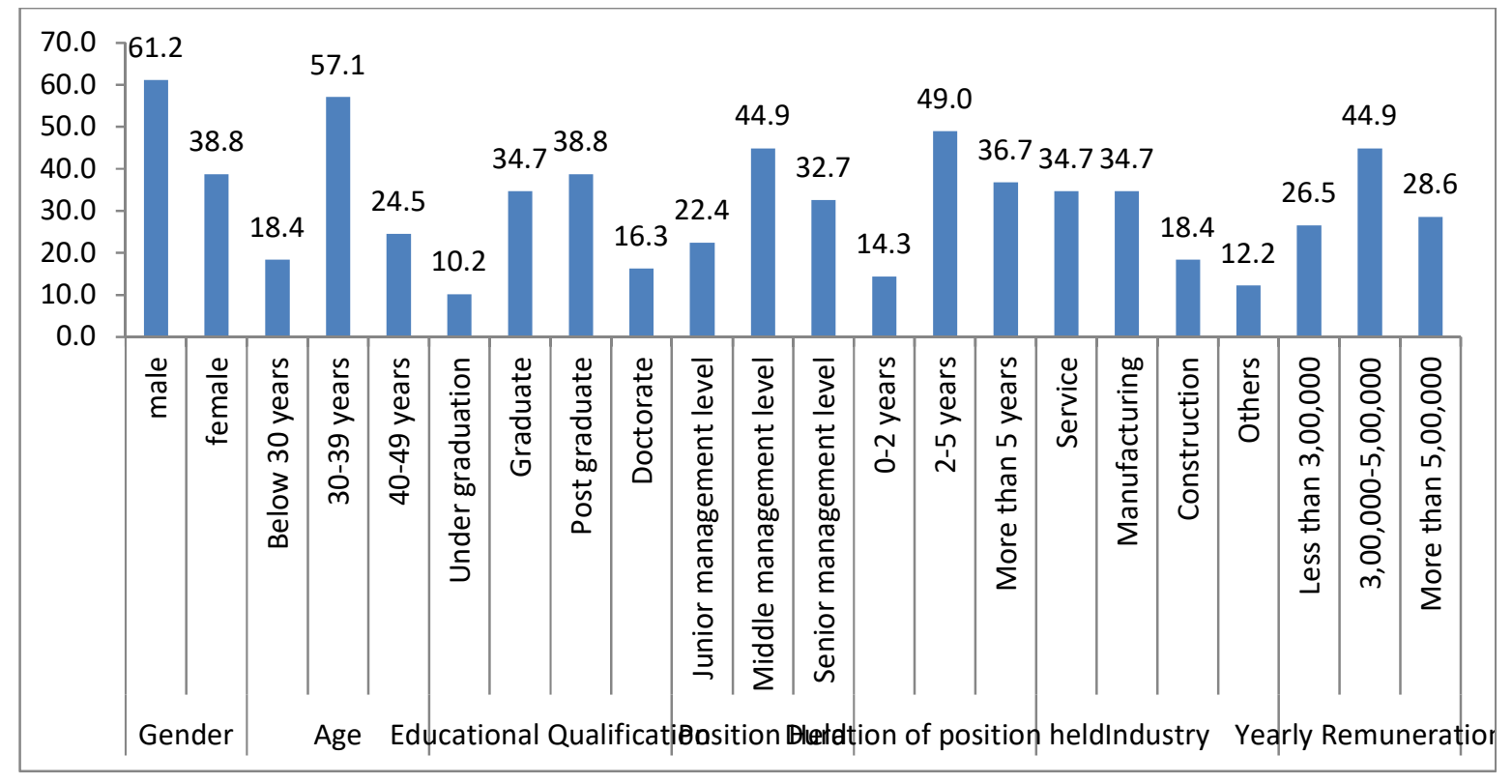

Fig. 2. Frequency distribution of demographic profile

This may appear from the fact that the percentage of women working in UAE at the national level is also low. $57.1 \%$ of the male and female population were of the age of 30-39 years. In addition, majority of the employees amongst the 5 entrepreneurial businesses have majorly post graduates $(38.8 \%)$ and graduates $(34.7 \%)$. This may appear from the fact that the ministry of education in UAE have been strictly focusing on tertiary and advanced education of the UAE students. In addition, entrepreneurial businesses need specialized task and students learn specialized skills only in post-graduation and advanced graduation studies. It was also found that, $44.9 \%$ of the respondents in the study were from middle management. The middle management is tasked with the most crucial work of managing its juniors and keeping the seniors in loop and hence they may have better understanding of the study. It was also found that, the participants were mainly from the service and manufacturing sector. This is evident that, majority of the entrepreneurial business globally are either from the IT sectors or manufacturing 
sector of innovative and sustainable products. Lastly, 44.9\% of the employees were found to earn 300,000 to 500,000 Emirati dirham annually.

\subsubsection{Frequency distribution of general background}

Fig. 3 indicates that $38.8 \%$ of the employees from the entrepreneurial businesses believe that their leaders have team entrepreneurship leadership qualities, whereas $36.7 \%$ of the participants believe that individual entrepreneurship leadership qualities. This may be from the fact that, majority of the businesses targeted for the study comprises of single platform where the entrepreneurs running the businesses possess different set of skills and expertise and helps in business development. In addition, many also believe that their leaders possess the individual entrepreneurship skill, because, these participants may work directly under a particular entrepreneur with set of skills different from others in the team. However, it was found that the $32.7 \%$ of the employees also believe that the leadership model has been followed for $6-12$ months, whereas only $12.2 \%$ says that the leadership structure has been in use less than 6 months. This may appear either because the employees are junior level or the structure underwent recent changes. This is also evident from the fact that, $59.2 \%$ participants believe that the leadership structure will not change in the coming recent years. This may be because the structure may have changed in the recent past because $44.9 \%$ of the participants said that the structure changed within a year.

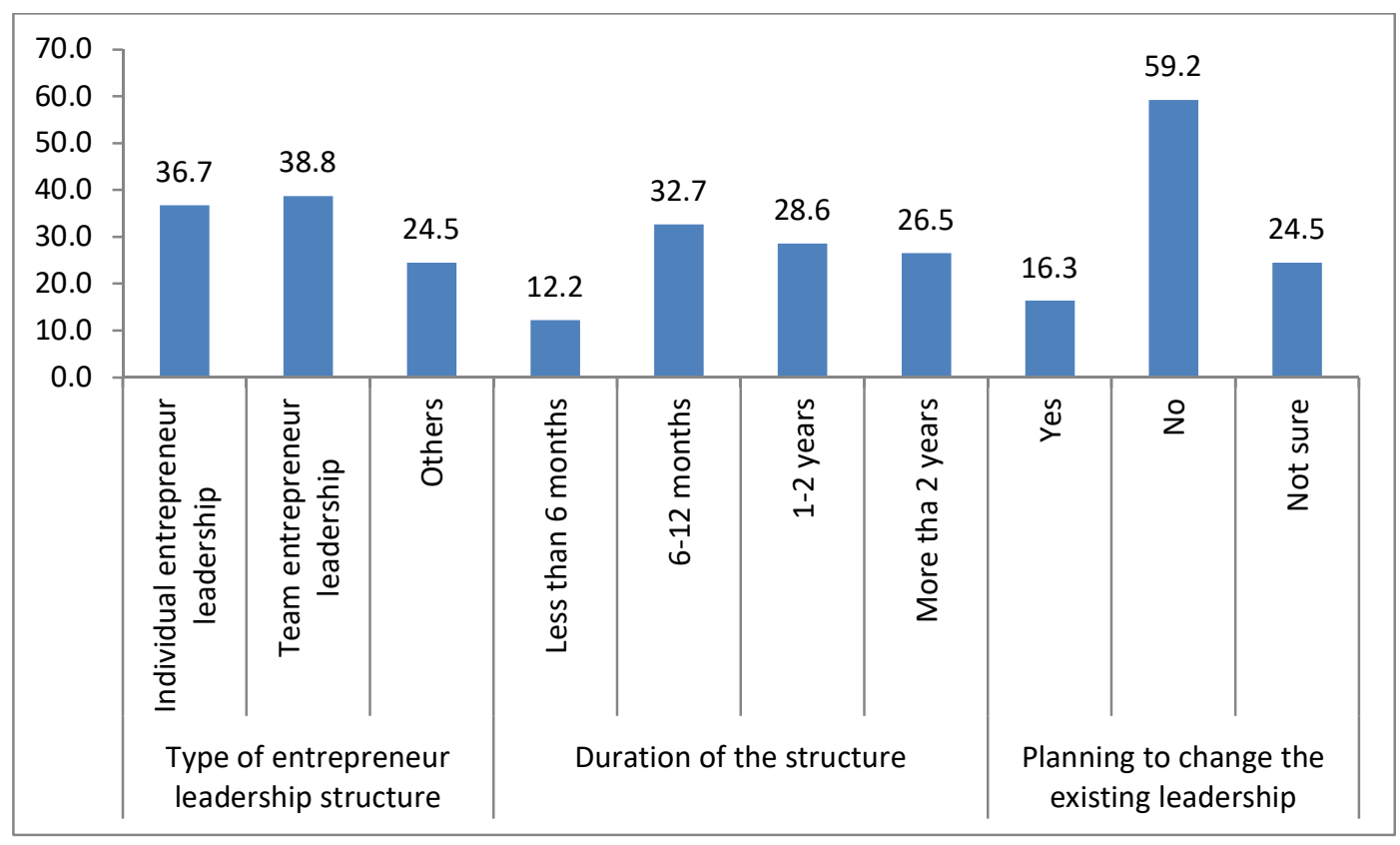

Fig. 3. Frequency distribution of general background

\subsubsection{Inferential analysis}

In this section, the study presented the findings from the correlations, ANOVA and regression test. In addition, this test was used to signify the null hypothesis of the study. The null hypothesis is:

$\mathrm{H}_{01}$ : There is no impact of Big-5 model traits of leadership on success of team entrepreneurship among small businesses in the UAE.

$\mathrm{H}_{02}$ : The personality traits of entrepreneurial teams have no impact on the business performance of the small ventures

\subsection{Correlation statistics}

According to Table 2, the correlation statistics between the personality traits and the business performance has been presented. The correlation statistics presents a very high relationship between the factors of various personality traits of entrepreneurial teams and the measures that indicate business performance. It was found that personality trait like cooperativeness of the team improves the stock values in the market by a high value of .740. Similarly, when the team is anxious over their business performance and the operations, it improves the sales and increases innovation of new products at high values of .783 and .867 respectively. Thus, the analysis implicates a high positive and significant impact of entrepreneurial traits on the performance of the businesses such as sales, customer base, innovation, stock values, diversification of skills, increase strength of the organization and competitiveness in the market. 
Table 2

Correlation statistics

\begin{tabular}{|c|c|c|c|c|c|c|c|c|c|c|c|c|}
\hline & & 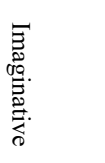 & 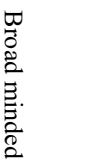 & $\begin{array}{l}\frac{T}{0} \\
\frac{x}{0} \\
\frac{\sigma}{0}\end{array}$ & 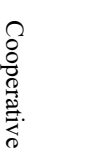 & $\begin{array}{l}\mathscr{N} \\
0 \\
\stackrel{0}{0} \\
\frac{\sigma}{0}\end{array}$ & 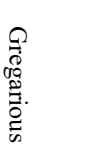 & 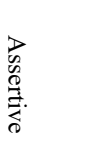 & $\begin{array}{l}\nabla \\
8 \\
0 \\
0 \\
0 \\
0 \\
0 \\
\frac{0}{0}\end{array}$ & 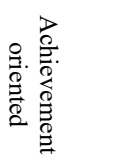 & 胥. & 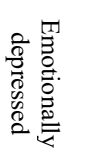 \\
\hline \multirow{3}{*}{$\begin{array}{l}\text { Increased sales } \\
\text { of } \\
\text { services }\end{array}$} & Pearson Correlation & $1.000^{* *}$ & $.777^{* *}$ & $.845^{* *}$ & $.777^{* *}$ & $.881^{* *}$ & $.796^{* *}$ & $.763^{* *}$ & $.848^{* *}$ & $.800^{* *}$ & $.783^{* *}$ & $.865^{* *}$ \\
\hline & Sig. (2-tailed) & .000 & .000 & .000 & .000 & .000 & .000 & .000 & .000 & .000 & .000 & .000 \\
\hline & $\mathrm{N}$ & 49 & 49 & 49 & 49 & 49 & 49 & 49 & 49 & 49 & 49 & 49 \\
\hline \multirow{3}{*}{$\begin{array}{l}\text { Innovation of } \\
\text { new products }\end{array}$} & Pearson Correlation & $.777^{* *}$ & $1.000^{* *}$ & $.795^{* *}$ & $.941^{* *}$ & $.775^{* *}$ & $.906^{* *}$ & $.889^{* *}$ & $.942^{* *}$ & $.820^{* * *}$ & $.867^{* *}$ & $.921^{* *}$ \\
\hline & Sig. (2-tailed) & .000 & .000 & .000 & .000 & .000 & .000 & .000 & .000 & .000 & .000 & .000 \\
\hline & $\mathrm{N}$ & 49 & 49 & 49 & 49 & 49 & 49 & 49 & 49 & 49 & 49 & 49 \\
\hline \multirow{3}{*}{$\begin{array}{l}\text { Increased stock } \\
\text { value }\end{array}$} & Pearson Correlation & $.845^{* * *}$ & $.795^{* *}$ & $1.000^{* *}$ & $.740^{* *}$ & $.882^{* *}$ & $.756^{* * *}$ & $.812^{* * *}$ & $.807^{* * *}$ & $.801^{* * *}$ & $.843^{* * *}$ & $.860^{* *}$ \\
\hline & Sig. (2-tailed) & .000 & .000 & .000 & .000 & .000 & .000 & .000 & .000 & .000 & .000 & .000 \\
\hline & $\mathrm{N}$ & 49 & 49 & 49 & 49 & 49 & 49 & 49 & 49 & 49 & 49 & 49 \\
\hline \multirow{3}{*}{$\begin{array}{l}\text { Increased com- } \\
\text { petitiveness in } \\
\text { the market }\end{array}$} & Pearson Correlation & $.777^{* *}$ & $.941^{* *}$ & $.740^{* * *}$ & $1.000^{* *}$ & $.703^{* *}$ & $.867^{* *}$ & $.889^{* *}$ & $.903^{* *}$ & $.840^{* * *}$ & $.867^{* *}$ & $.882^{* *}$ \\
\hline & Sig. (2-tailed) & .000 & .000 & .000 & .000 & .000 & .000 & .000 & .000 & .000 & .000 & .000 \\
\hline & $\mathrm{N}$ & 49 & 49 & 49 & 49 & 49 & 49 & 49 & 49 & 49 & 49 & 49 \\
\hline \multirow{3}{*}{$\begin{array}{l}\text { Diversification } \\
\text { of venture } \\
\text { skills }\end{array}$} & Pearson Correlation & $.881^{* *}$ & $.775^{* *}$ & $.882^{* *}$ & $.703^{* *}$ & $1.000^{* *}$ & $.702^{* *}$ & $.776^{* * *}$ & $.788^{* * *}$ & $.807^{* * *}$ & $.775^{* *}$ & $.877^{* *}$ \\
\hline & Sig. (2-tailed) & .000 & .000 & .000 & .000 & .000 & .000 & .000 & .000 & .000 & .000 & .000 \\
\hline & $\mathrm{N}$ & 49 & 49 & 49 & 49 & 49 & 49 & 49 & 49 & 49 & 49 & 49 \\
\hline \multirow{3}{*}{$\begin{array}{l}\text { Increased num- } \\
\text { ber of members } \\
\text { of the venture }\end{array}$} & Pearson Correlation & $.796^{* *}$ & $.906^{* *}$ & $.756^{* *}$ & $.867^{* *}$ & $.702^{* *}$ & $1.000^{* *}$ & $.835^{* *}$ & $.905^{* *}$ & $.798^{* *}$ & $.829^{* *}$ & $.884^{* *}$ \\
\hline & Sig. (2-tailed) & .000 & .000 & .000 & .000 & .000 & .000 & .000 & .000 & .000 & .000 & .000 \\
\hline & $\mathrm{N}$ & 49 & 49 & 49 & 49 & 49 & 49 & 49 & 49 & 49 & 49 & 49 \\
\hline \multirow{3}{*}{$\begin{array}{l}\text { Increased cus- } \\
\text { tomer base }\end{array}$} & Pearson Correlation & $.763^{* *}$ & $.889^{* *}$ & $.812^{* *}$ & $.889^{* *}$ & $.776^{* *}$ & $.835^{* *}$ & $1.000^{* *}$ & $.870^{* *}$ & $.784^{* * *}$ & $.886^{* *}$ & $.868^{* *}$ \\
\hline & Sig. (2-tailed) & .000 & .000 & .000 & .000 & .000 & .000 & .000 & .000 & .000 & .000 & .000 \\
\hline & $\mathrm{N}$ & 49 & 49 & 49 & 49 & 49 & 49 & 49 & 49 & 49 & 49 & 49 \\
\hline
\end{tabular}

\subsection{ANOVA test}

In Table 3, the statistics found a very high regression value. It was found that $96.7 \%$ of all the responses of the employees from the 5 businesses fall on the regression line. In other words, it may be implicated that majority of sub-leadership traits from the Big 5 were found to have similar type of responses and that these traits may significantly impact the team entrepreneurship among small businesses of UAE. Moreover, this is indicative from the fact that the significance of the study was found to be $.000(\leq 0.05)$. However, this finding is not explicit as the most significant factors or traits of leadership are found using the coefficient of regression statistic. However, it may be implicated that the null hypothesis will be rejected. In addition, the Table 3, also found a very high regression value. It was found that $97 \%$ of all the responses of the employees from the 5 businesses fall on the regression line. In other words, it may be implicated that majority of business performance measures were found to have similar type of responses and that these performance values may significantly get impacted by the team entrepreneurship personality traits among small businesses of UAE. Moreover, this is indicative from the fact that the significance of the study was found to be $.000(\leq 0.05)$. However, this finding is not explicit as the most significant factors or traits of leadership are found using the coefficient of regression statistic. However, it may be implicated that the null hypothesis will be rejected.

Table 3

ANOVA statistics

\begin{tabular}{lccccc}
\hline & $\mathrm{R}$ & R Square & Adjusted R Square & F value & Sig \\
\hline Traits & .987 & .974 & .967 & 127.684 & .000 \\
Performance & .970 & .940 & .930 & 92.059 & .000 \\
\hline
\end{tabular}

\subsection{Regression test Model 1}

The regression statistics found in the Table 4 indicates that 6 out of 11 entrepreneurial traits were found to have a significant value of less than 0.05 at a confidence level of $95 \%$. Factors such as broad minded (.006), gregarious (.015), assertive (.006), responsible (.003), anxious (.049) and emotionally depressed (.000) were found to be the most significant traits perceived by the employees of the 5 entrepreneurial small businesses in UAE to impact team entrepreneurship in their organizations. A similar study was conducted by Khan et al. (2016) using the sub-traits of the Big 5 in the sports industry. However, the study found that traits such as emotional stability, extroversion, broad minded, gregarious and openness to experience were statistically significant to influence sports people for better performance. Again, Baker et al. (2016) conducted a similar study supporting the current findings. The study used the impact of Big 5 on leadership intentions of young women and found that factors like cooperative, sociable, self-efficacy, and social potency were the most important factors to signify the intentions of young women. In this regard, it may be said that the current study rejects the null hypothesis that there is no impact of Big5 model traits of leadership on team entrepreneurship among small businesses in the UAE. The alternative hypothesis is accepted, and it may be implicated that there is positive and significant impact of Big-5 model traits such as broad minded, gregarious, assertive, responsible, anxious and emotionally depressed on team entrepreneurship among small businesses in the UAE. 
Table 4

Regression statistics Model 1

\begin{tabular}{lcc}
\hline Traits & $\mathrm{t}$ & Sig. \\
\hline Imaginative & -.486 & .630 \\
Broad minded & 2.915 & $\mathbf{0 0 6}$ \\
Flexible & -1.851 & .072 \\
Cooperative & .015 & .988 \\
Sociable & -.556 & .582 \\
Gregarious & -2.539 & $\mathbf{. 0 1 5}$ \\
Assertive & 2.900 & $\mathbf{0 0 6}$ \\
Responsible & 3.208 & $\mathbf{0 0 3}$ \\
Achievement oriented & .908 & .370 \\
Anxious & -2.038 & $\mathbf{. 0 4 9}$ \\
Emotionally depressed & 4.150 & $\mathbf{0 0 0}$ \\
\hline
\end{tabular}

On the other hand, coefficient of regression in case of business performance, it was found that the measures of business performance such as innovation of new products (.000), increased stock value (.044), diversification of venture skills (.029) and increased customer base (.010) were found to be the most significant business performance values and measures for the small ventures chosen in the study. In addition, it may also be implicated that the personality traits of entrepreneurial teams in UAE impacts on the business performance by innovating new products, increased stock value, diversification of venture skills and increased number of customer base. Therefore, the null hypothesis of the study which is personality traits of entrepreneurial teams have no impact on the business performance of the small ventures is rejected and the alternative hypothesis is accepted. This means personality traits of entrepreneurial teams have positive and significant impact on the business performance of the small ventures in UAE.

Table 5

$\underline{\text { Regression statistics Model } 2}$

\begin{tabular}{lcc} 
Business performance & $\mathrm{t}$ & Sig. \\
\hline Increased sales of services & .669 & .507 \\
Innovation of new products & 4.622 & .000 \\
Increased stock value & -1.772 & .044 \\
Increased competitiveness in the market & .487 & .629 \\
Diversification of venture skills & 1.053 & .029 \\
Increased number of members of the venture & -.396 & .694 \\
Increased customer base & 1.671 & .010 \\
\hline
\end{tabular}

\section{Conclusion}

The current study has used the big five leadership traits which are; openness to experience, conscientiousness, extraversion, agreeableness and neuroticism. Literatures have found that team entrepreneurship comprises of single platform through which individual entrepreneurs possessing different set of skills and expertise can come together to share their ideas, resources and competencies. In addition, the study literatures found that UAE has become the fastest growing business markets causing a rise in the number of small-scale enterprises. These small-scale enterprises have made numerous contributions to the innovation domain in the Middle Eastern region. In this regard, the main aim of the study is to explore the impact of Big-5 model traits of leadership on team entrepreneurship among small businesses in the UAE. Using empirical findings it is not evident that the big five leadership traits of openness to experience, conscientiousness, extraversion, agreeableness and neuroticism have significant impact on team entrepreneurship. It was statistically evident that sub-leadership traits of the big five mainly broad minded, gregarious, assertive, responsible, anxious and emotionally depressed are more significant in the case of UAE small enterprises. However, it was also implicated that these traits of the entrepreneurial teams have direct impact on the business performance of their ventures. The most important business performances found were increased sales of services, innovation of new products, increased stock value, increased competitiveness in the market, diversification of venture skills, increased number of members of the venture and increased customer base. Therefore, the study may help the existing and upcoming entrepreneurs to improve their leadership traits of openness to experience, conscientiousness, extraversion, agreeableness and neuroticism so as to lead an organization as well as help improve the performance of the organization. In addition, the study also helps the existing leaders to ponder upon their current leadership traits and the need to improve the traits of imaginative, flexible, cooperative, and sociable and achievement oriented. In addition, traits must also be improved to improve business performance on the basis of improving the sales, strength of the venture and increase the competitiveness in the market. In the future studies, larger groups of team entrepreneurs and employees from smaller entities must be surveyed not only in UAE, but also in other Middle Eastern regions. In addition, future studies must also use qualitative studies and interview the entrepreneurial leaders with respect to the leadership strategies used to develop their traits and understand other aspects of leadership on performance of the organization. 


\section{References}

Antoncic, B., Bratkovic Kregar, T., Singh, G., \& Denoble, A. F. (2015). The Big Five Personality-Entrepreneurship Relationship: Evidence from Slovenia. Journal of Small Business Management, 53(3), 819-841.

Antoncic, B., Hisrich, R. D., Coelho, A., Gantar, M., Marks, L. J., Bachkirov, A. A., ... Polzin, P. (2018). Risk-Taking Propensity and Entrepreneurship: The Role of Power Distance. Journal of Enterprising Culture, 26(01), 1-26.

Brandstätter, H. (2011). Personality aspects of entrepreneurship: A look at five meta-analyses. Personality and Individual Differences.

Darnihamedani, P. (2016). Individual Characteristics, Contextual Factors and Entrepreneurial Behavior, 1-180.

Diakanastasi, E., Karagiannaki, A., \& Pramatari, K. (2018). Entrepreneurial Team Dynamics and New Venture Creation Process: An Exploratory Study Within a Start-Up Incubator. SAGE Open.

Farwizah, F., Rahim, M., \& Rahim, H. A. (2018). The Effect of Personality Traits ( Big-Five ), Materialism and Stress on Malaysian Generation Y Compulsive Buying Behaviour The Effect of Personality Traits ( Big-Five ), Materialism and Stress on Malaysian Generation Y Compulsive Buying Behaviour. International Journal of Academic Research in Business and Social Sciences, 8(7), 349-362.

George, D. (2018, December 4). Entrepreneurs to drive UAE's future economic growth. Gulf News Business.

Goldberg, L. (1981). Language and Indi-vidual Differences: The Search for Universalsin Personality Lexicons. Review of Per-Sonality and Social Psychology, 2, 141-165.

Goldberg, L. (1990). An Alternative 'Description ofPersonality': The Big Five Factor Structure. Journal of Personality and Social Psychology1, 59, 1216-1229.

Hamdan, A. (2019). Entrepreneurship and Economic Growth: An Emirati Perspective. The Journal of Developing Areas, $53(1), 65-78$.

Hwee Nga, J. K., \& Shamuganathan, G. (2010). The influence of personality traits and demographic factors on social entrepreneurship start up intentions. Journal of Business Ethics.

Kamm, J. B., Shuman, J. C., Seeger, J. A., \& Nurick, A. J. (2018). Entrepreneurial Teams in New Venture Creation: A Research Agenda. Entrepreneurship Theory and Practice. https://doi.org/10.1177/104225879001400403

Kerr, S. P., Kerr, W. R., \& Xu, T. (2018). Personality Traits of Entrepreneurs: A Review of Recent Literature. Foundations and Trends ${ }^{\circledR}$ in Entrepreneurship, 14(3), 279-356.

Khan, M. S., Breitenecker, R. J., \& Schwarz, E. J. (2014). Entrepreneurial team locus of control: Diversity and trust. Management Decision, 52(6), 1057-1081.

Kuckertz, A., \& Berger, E. S. C. (2017). Entrepreneurship: Entrepreneurial Individuals and Entrepreneurial Teams. Entrepreneurship and Innovation Management, 1755, 112-124.

Kumaran, K., Nair, V., \& Venumadhav. (2017). To Study The Entrepreneur's Personality Traits Which Affect The Success of Digital Entrepreneurs in India. IOSR Journal of Computer Engineering, 36-41.

Markuerkiaga, L., Errasti, N., \& Igartua, J. I. (2014). Success factors for managing an entrepreneurial university: Developing an integrative framework. Industry and Higher Education, 28(4), 233-244.

Matriano, M. T., \& Suguku, D. (2015). Entrepreneurship Growth in Oman: Position, Prospects and Growth of Entrepreneural Education. IJAEDU- International E-Journal of Advances in Education, 1(2), 127.

Maxwell, J. A. (2013). Personality Traits among Entrepreneurial and Professional CEOs in SMEs. International Journal of Business and Management, 5(9), 203-213.

Murugesan, R., \& Jayavelu, R. (2017). The Influence of Big Five Personality Traits and Self-efficacy on Entrepreneurial Intention: The Role of Gender. Journal of Entrepreneurship and Innovation in Emerging Economies, 3(1).

Narea, J. O. (2016). Entrepreneurial Traits and Innovation: evidence from Chile. Universitaire Pers Maastricht, 1-204.

Schilirò, D. (2015). Innovation in Small and Medium Enterprises in the United Arab Emirates. International Journal of Social Science Studies, 3(5). https://doi.org/10.11114/ijsss.v3i5.1014

Shane, S. (2010). Entrepreneurship and the big five personality traits: A behavioral genetics perspective. Unpublished Working Paper, 1-35.

Singh, S. (1997). Personality, Motives and Entrepreneurial Success. Indian Journal of Industrial Relations, 33(2), $254-260$.

Skripak, S. J. (2016). Entrepreneurship: Starting a Business. In Fundamentals of Business (pp. 132-162). Virginia: Saylor Foundation.

Ugwoke, D., Kalu, E., \& Lauretta, C. (2013). Perceived Locus of Control as a Predictor of Entrepreneurial Development and Job Creation among Students in the Tertiary Institution, 4(14), 49-55.

Vyakarnam, S., \& Handelberg, J. (2005). Four themes of the impact of management teams on organizational performance: Implications for future research of entrepreneurial teams. International Small Business Journal, 23(3), 236-256.

Wilfling, S., \& Silbereisen, R. K. (2011). WHICH BIG-FIVE PERSONALITY TRAITS DRIVE ENTREPRENEURIAL FAILURE Which Big-Five personality traits drive entrepreneurial failure in highly innovative industries ? DIME-DRUID ACADEMY Winter Conference, (May 2014).

Yan, J. (2010). The Impact of Entrepreneurial Personality Traits on Perception of New Venture Opportunity. New England Journal of Entrepreneurship, 13(2), 1-15.

Yan, J. (2018). The impact of entrepreneurial personality traits on perception of new venture opportunity. New England Journal of Entrepreneurship, 13(2), 21-35.

Yoon, H. (2018). Exploring the role of entrepreneurial team characteristics on entrepreneurial orientation. SAGE Open, 8(2), 2158244018777025. 
Zaccaro, S. J., Rittman, A. L., \& Marks, M. A. (2001). Team leadership. Leadership Quarterly, 12(4), 451-483.

Zhao, H., \& Seibert, S. E. (2006). The big five personality dimensions and entrepreneurial status: A meta-analytical review. Journal of applied psychology, 91(2), 259.

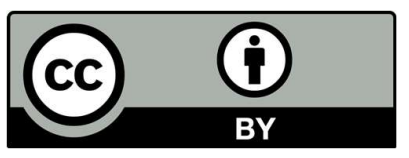

(C) 2020 by the authors; licensee Growing Science, Canada. This is an open access article distributed under the terms and conditions of the Creative Commons Attribution (CCBY) license (http://creativecommons.org/licenses/by/4.0/). 